\title{
Pacific history matters
}

Brij V. Lal

\section{(2) OpenEdition}

\section{Journals}

Electronic version

URL: http://journals.openedition.org/jso/894

DOI: $10.4000 /$ jso.894

ISSN: $1760-7256$

\section{Publisher}

Société des océanistes

\section{Printed version}

Date of publication: 1 December 2007

Number of pages: 193-200

ISBN: 978-2-85430-010-9

ISSN: 0300-953x

\section{Electronic reference}

Brij V. Lal, «Pacific history matters », Journal de la Société des Océanistes [Online], 125 | Année 2007-2, Online since 01 December 2010, connection on 01 May 2019. URL : http://journals.openedition.org/ jso/894 ; DOI : 10.4000/jso.894 


\section{Pacific history matters}

by

Brij V. LAL*

ABSTRACT

New Pacific historiography emerged at a particular place and time and in a particular political context. Its founding charter promoted an island-centred approach to historical scholarship. But since its solitary beginnings in the 1950s, the sub-discipline of Pacific has taken new turns and broadened its scope. Canberra's founding role is acknowledged, but other centres have emerged to make their own distinctive contribution. More islanders are participating in academic discourses about the islands' past. And history is practised and performed in new, innovative ways that challenge the discipline's foundational approach and framework.

Keywords: Pacific historiography, Canberra School, JW Davidson, Pacific Studies, Australian National University, Island-oriented history.

\section{RÉSUMÉ}

La nouvelle historiographie Pacifique est née à un moment, à une place et dans un contexte politique bien particuliers. Sa charte de fondation a promu une approche des études historiques centrée sur les îles. Dès ses débuts en 1950, cette sous-discipline du Pacifique a pris de nouvelles directions et élargi sa perspective. Si le rôle fondateur de Canberra est reconnu, d'autres centres ont émergé qui ont apporté leur propre contribution. Un nombre grandissant d'insulaires participent aux discours savants tenus sur le passé des îles. Et l'histoire se pratique et s'exerce aujourd'hui le long d'axes novateurs qui défient le cadre et les fondations de la discipline.

Mots-CLÉs : historiographie du Pacifique, école de Canberra, J. W. Davidson, études du Pacifique, université nationale australienne (ANU), histoire centrée sur les îles.

«The difficulty with theories of essentialism and exclusiveness, or with barriers and sides, is that they give rise to polarizations that absolve and forgive ignorance and demagogy more than they enable knowledge»

Edward Said, Culture and Imperialism.

The academic genealogy of Pacific History, unlike most other fields of history, is clearly established and widely accepted ${ }^{1}$. The ancestral founder of the clan is James Wightman Davidson. The place of the founding, the clan's sacred shrine, is the Department of Pacific History of the Research School of Pacific Studies at The Australian National University, in Canberra. And the clan's sacred motto, its tribal ideology, is the pursuit of an island-oriented investigation

1. This paper is based substantially on my address to the Marseilles conference of the ESfO, 2005. I acknowledge the invitation to speak and thank Donald Denoon and Hank Nelson for their trenchant comments.

* Division of Pacific and Asian History, Research School of Pacific and Asian Studies, The Australian National University, brijlal@coombs.anu.edu.au 
of the Pacific's past. For well over a generation, its descendants, steeped in the sacred rituals, spread across the globe to preach their message. In due course, a new and powerful priestly class emerged to preside over a dominant orthodoxy. Half a century later, the shrine still exists, re-named and reshaped and reduced in response to the needs and demands of changing times. New members have been inducted, adding colour and diversity, and occasional disagreements. And the dominant ideology is contested by counter-claims and other sometimes defiant voices seeking to be heard.

Canberra's altered role and status as the sole shrine of Pacific history has mystified some and disappointed others, especially its earlier graduates. Canberra, they say, has let the field down, become inward looking, complacent, unresponsive to calls for reform and leadership. The present is severely wanting when measured against the grand achievements of a golden age. Some of this criticism is obviously tainted by romanticism. In truth, the early years were not as bountiful in terms of graduate training, research productivity and innovative scholarship as is sometimes thought. The founders themselves wrote rather less than might have been expected. Canberra's islander-oriented approach did not strike some as being particularly revolutionary, even for its time. One Pacific historian put it to me privately:

«As the Indians had put Indians in Indian history, Africans had put Africans in African history, the notion of putting Pacific Islanders in Pacific Island history did not strike us as new.»

And rather more has been achieved since the 1970 s than is generally acknowledged, especially on the social and political history of Melanesia, particularly Papua New Guinea, an area of great interest to Australia curiously neglected by Davidson's department. The difference is that more of the earlier graduates secured academic appointments, while their later counterparts had to seek employment in the private and public sector, their dissertations and theses unpublished. Today, for all the problems of resources, Canberra still produces the largest number of Pacific history graduates.

The perception of Canberra's decline is attributable to many factors, among them the emergence of other centres of Pacific studies in the islands themselves, in New Zealand where every major university has at least one Pacific historian, and in Hawaii and elsewhere. By comparison, the teaching of undergraduate Pacific history in Australia has declined dramatically. This alarming situation itself is partly the result of declining enrolments in the humanities. Economic realities force students to choose courses which promise better employment possibilities. For that, Asia may offer better prospects than the Pacific. Other students have who might have once taken history have moved into the adjacent area of Cultural Studies.

The Research School of Pacific Studies is now re-named the Research School of Pacific and Asian Studies. Similarly, the Department of Pacific (and later Southeast Asian) History, which trained an earlier generation of Pacific historians, is now one of four sections in the Division of Pacific and Asian History, sharing space and resources with China, Japan, Korea and Southeast Asia. Furthermore, the School's research and staffing priorities do not have the Pacific Islands as one of its top four priority areas (China, Japan, Indonesia and Papua New Guinea). Within the Pacific, focus will shift to the Southwest Pacific (Melanesia, including Fiji), the region of Australia's principal strategic and economic interests, a region on which ANU's research profile has long been indisputably pre-eminent.

The islands of Polynesia, the site of so much of the early work in Pacific history - Jim Davidson and Richard Gilson on Samoa, Harry Maude on the Gilberts and Ellice Islands, Richard Gilson and Ron Crocombe on the Cooks, Sione Latukefu and Noel Rutherford on Tonga, Niel Gunson on Christian missions in Polynesia - will be accorded less attention, on the grounds that other places are better suited to study them. New Zealand, for instance, for geographical, cultural and political reasons - it is now the home of substantial Pacific island communities and increasingly views itself as a Pacific Island nation - is felt to be the appropriate place for post-graduate work on Polynesia, just as Hawaii and Guam are the natural centres for the study of Micronesia.

The School's priorities also demand more attention on the more recent colonial and postcolonial periods, in marked contrast to the earlier generation of Pacific scholarship which focused on the early contact period, which long dominated Pacific historiography. Colonialism was a compromised subject disdained by proper Pacific historians. Kerry Howe recalls his contemporaries looking "askance at those few unfortunates amongst us who had somehow chosen to deal with "tainted" colonial topic. " (Howe, 1992: 228). The more recent period was left to geographers, economists and others, which was ironic given Davidson's and Maude's 
own involvement in contemporary affairs. Today, Pacific historians are expected to be engaged intellectually with contemporary developments. They are asked to comment regularly on radio, television and in print on topical issues. This engagement is assessed and rewarded in various ways. The trend towards more presentoriented research is also encouraged by the funding climate. Increasingly, governments support research which contributes to public debate and/or assists in the formulation of national aid policies. Relevance and the public good are the key words in the funding lexicon.

Adversities also provide opportunities to think creatively about new alignments and to forge new linkages. One way out is to explore closer ties with new «disciplines» such as cultural studies which, in their peculiar ways, address issues, topics, themes, which are a part of the historian's terrain: gender, identity, art, indigenous representations. There are other possibilities. Pacific Islands history, as we have known and taught it, focusing on the islanders in their interaction with the outside world and with each other, may have to be reformulated. In a nontraditional department, more creative proposals might be entertained to achieve the same goal. For instance, a course on Diasporas, the subject of considerable contemporary appeal around which a sophisticated body of theoretical literature has now developed. A course on Pacific diasporas would appeal to students in Anthropology, Cultural Studies, Demography, Sociology and Post-colonialism. One could trace migration roots and routes (Polynesians in New Zealand, Islander communities in Australia; Asian communities in Fiji and Hawaii, Chinese communities across the Pacific); questions of cultural identity and social change; the impact of a remittance economy on small island states; literary representations of the immigrants' experiences; the tensions between the demands of indigenous rights and the rights of the more recently arrived migrants. One could examine the rights and interests of diasporas in various international conventions. The advantage of this approach is not only its topical appeal - no small matter these days - but more importantly, because it helps break obsolete geographic barriers.

Intellectual innovation, then, is one way forward. Another is institutional cooperation. A number of universities have centres of Pacific studies, each with its own charter, special constituencies and institutional responsibilities. The University of the South Pacific has its Institute of Pacific Studies which under the leadership of its indefatigable founder, Ron Crocombe, published hundreds of morale-boosting books authored or co-authored by Pacific islanders, not all of them academics. The University of Canterbury's Macmillian Brown Centre for Pacific Studies has conducted workshops and hosted visiting scholars. The Centre for Pacific Studies at Auckland has been involved in teaching Pacific languages and strengthening community links with the university. And the University of Hawaii's Center for Pacific Islands Studies has a deservedly respected publication program. Much of this work is done in isolation; there is, so far as I know, little exchange of ideas about common interests and common projects, which is especially lamentable in this age of instantaneous communication. Institutional rivalry and competition will do us no good. We need to think collectively about the survival of our field.

Cooperation is possible if we are determined enough to pursue it. Donald Denoon's massive Cambridge History of the Pacific Islanders is a case in point. Denoon assembled a team of editors based in Sydney, Canterbury, Auckland and Honolulu, and together they commissioned a host of authors in different fields. That collective work harnessed the best of the contemporary scholarship on the islands and the book has already found a valuable place on many university reading lists. A few years earlier, Robert Kiste, Kerry Howe and I, based in Honolulu, Palmerston North and Canberra, collaborated with contributors in several countries to produce The Tides of History: Pacific Islanders in the Twentieth Century (1994). The Encyclopaedia of the Pacific Islands, housed in and supported by the ANU and edited by me, drew on the expertise and advice of an international Editorial Board, with hundreds of contributors based in countries across the world. The Pacific Manuscript Bureau, again based at the ANU since its inception in 1968, and which has microfilmed and distributed more than 3000 reels of primary material since then, is sponsored by libraries in Australia, New Zealand, Hawaii and California (Cunningham and Maidment, 1996: 443-455). It gained a new lease of life, and promises of continued funding, when it broadened its mission to contemporary developments (the Bougainville crisis, the Fiji coups, papers of trade unions and non-governmental organisations) in addition to preserving «at-risk» material in the islands, principally in the form of letters and diaries of early traders and missionaries.

Let us consider some other ways in which Pacific history is being re-shaped. The Davidson tradition was characterised by certain features 
which have been well summarised by Niel Gunson, one of Davidson's select band of selfdescribed «boomerang boys». Davidson, Gunson says:

«did not like jargon and distrusted those who sought to impose doctrinaire solutions on their problems whether new structuralists or old Marxists.»

The human mind or the creative spirit should not be shackled by arid theory, which should reflect rather than determine experience. Historians should learn and, where appropriate, borrow from cognate disciplines, such as Anthropology, «but never [be] wholly subject to them or their terminology» (Gunson, 1992: 6-7). Unlike other social scientists, they should paint on the broader canvass, and seek, in so far as the sources allow, change and continuity in human affairs. In that search, the historian's own direct involvement, through fieldwork, learning the language and culture of the people of one's study, even through direct involvement in public affairs, played an important part. History had a meaning and a role in the wider community. Davidson's own involvement in advising island governments in their constitutional evolution in Samoa, Nauru, Micronesia and Papua New Guinea, exemplified his ideal of the scholar in action. It was by this work more than his more conventional writing that Davidson wanted to be remembered.

Harry Maude, Davidson's long-term colleague, espoused similar views. He had entered academia after a career as a colonial civil servant in the central Pacific, principally in the Gilberts and Ellice islands about whose past he wrote in elegantly crafted, exhaustively documented articles. $\mathrm{He}$, too, believed that history had a constructive role in society. Maude wrote in 1971 that Pacific history:

«is not only a fascinating specialization in its own right, studying a regional laboratory of historical variables in miniature that will enable it to make an interesting contribution to the discipline as a whole, but that it also has a very practical and therapeutic role to enact in assisting the rehabilitation of the Pacific peoples at the end of a traumatic era of European political, economic and technological ascendancy by renewing their self-respect and providing them with a secure historical base from which to play their part as responsible citizens of independent or self-governing communities in a new world.» (Maude, 1971: 24)

Scholarship as social and moral responsibility, not private indulgence, scholarship in the service of a cause, as constructive and committed engagement: these were the values which guided Davidson's and Maude's historical vision.
Their approach and work has been subjected to both fair and unfair criticism. Dorothy Shineberg has rightly noted Davidson's romantic fascination with Polynesia, his instinctive attraction towards the complex politics of hierarchical societies, his deft understanding of high politics (Shineberg,1996: 1-16). For Davidson, Polynesian institutions were "of a highly sophisticated kind», whereas Melanesian political institutions «were of a more primitive kind,» where chieftainship was «far less highly developed», the scale and scope of political authority limited and where national states did not exist (Davidson, 1966: 11-12). Davidson's sympathies and prejudices are clear. But more than his regional and cultural bias is criticised. The kind of history he and his colleagues did and promoted is dismissed today as the relics of an era of conventional, empiricist, theoretically innocent scholarship (Thomas, 1990: 139-158). Needless to say, selfcriticism is vital, but our exuberant enthusiasm for new ways or for our own work, should be tempered by a more sympathetic awareness of the efforts and achievements of others which, in turn, must be seen and assessed in the context of time and place and circumstance. Davidson and his disciples filled gaps and raised building blocks; they played - more than played - their part in rescuing a field from the unlovely fringes of colonial and imperial history and giving it a new identity. It is easy to shoot fish in a bowl.

Nonetheless, the revisionists have a point. The notion of an «island-oriented» history raises as many questions as it resolves. Islands consist of people, men and women, elites and commoners, of privileged and underprivileged regions, of sahibs and subalterns, who speak with different voices and have different interests and understandings. To attribute homogeneity and uniformity of motive, interest and behaviour to such a disparate group is problematic. The world view of islanders is often fragmented and contested, divided over ancient prejudices and modern greeds. Often, those who purport to speak on behalf of islanders or write an island-oriented history, end up privileging the voices of the educated, articulate elite or cataloguing the machinations of high traditional politics. And often they attribute a single-mindedness to the motives of outsiders who themselves are just as often racked by conflict of interests. Multivocality cuts both ways.

Islander-agency and the rejection of «fatal impact» which formed the core of the Davidson school, have also been criticised. The point is taken that islanders were not passive bystanders in the process of culture contact. They were 
adept at safeguarding their interests, and embroiling outsiders in their own disputes and manipulating them to their advantage. The very presence of vibrant communities of Pacific islanders contradicts the notion of «fatal impact». Critics, including some earlier advocates of islander agency, now point out that there were places - Hawaii, New Caledonia, New Zealand, Australia - where the impact through land alienation, physical and cultural violence and introduced diseases such as smallpox and influenza was pretty «fatal» in the broad rather than literal sense of the word. In colonies of large-scale European settlement, the indigenous people are on the economic and political margins of society.

Even where the impact of colonial rule has generally been thought to be benign, new evidence points to a great disparity between rhetoric and reality. In Fiji, for instance, Sir Arthur Gordon's rule is criticised for imposing uniform order on a complex and fluid situation that served to marginalise those who refused to cooperate (Kaplan, 1989: 349-371; Thomas, 1990: 149170 and France, 1969). In Samoa, Wilhelm Solf's legacy is subjected to critical scrutiny. «The new historiography is in danger of promoting a new orthodoxy» Malama Meleisea writes, «if it tries to diminish the tragic consequences of land grabbing, king-making, and gun boat diplomacy by Europeans in destroying the political capacities of Islanders to respond on equal terms» (Meleisia, 1985). Stewart Firth has made a similar point. To depict Pacific Islanders as «exploited victims of the Europeans has become close to a sin in the new Pacific historiography», he has argued.

«In fact, the islanders did not triumph. The island economies are still today owned by foreigners. Political independence, where it has been achieved, is limited.» (Firth, 1979: 128)

Barrie Macdonald has reminded us of two further and related issues (Munro, 1996: 23-44) He suggests that one inadvertent effect of the island focus has been the neglect of larger extraregional forces which have had significant effect on island life, particularly in the 20th century. And the emphasis on the early contact and colonial period has been at the cost of focus on more recent times. The result of this bias has been that, with a few notable exceptions, Pacific historians have had little to say about Pacific's present, leaving the field to other social scientists. Naturally, if our students see us as irrelevant to their concerns and to the concerns of the larger society, we must be partly responsible. The island-centred approach also isolated Pacific history from the broader context of international influence and change, argues Macdonald. The comparative experience of colonialism, political development, cultural change, decolonisation in Africa and Asia had no meaning for Pacific historians (Munro, 1996: 45-68).

Pacific history has always been determinedly empirical in approach and content. Its preoccupation with detail and documentation led to what Howe called the "monograph myopia», «finding out more and more about less and less», without any «basic sense of direction» (1979). Dening agrees:

«The empiricism that dominates most Pacific study is the root of the problem. Research is dominated by a narrow geographical area, an institution, a period. History is what happens or what the sources let us know what happens within those limitations. No problem, no theory, no methodology takes the researcher outside those confines.» (ibid.)

The point needs no debating. In recent years, however, many scholars have broadened their horizons to inform themselves of the perspectives of other disciplines, particularly anthropology (Lal, 1992: 92-106). In the hands of accomplished practitioners, the result can be dazzling: note the debate between Marshall Sahlins and Gananath Obeysekere on the explanation of the death of Captain Cook (Sahlins, 1995; Obeysekere, 1992). Bernard Cohn, the distinguished historian and anthropologist of South Asia, in another context, has demonstrated how fruitful collaboration between the two disciplines can produce unique and invaluable insights (1990).

A note of caution is necessary, even in these times of free border crossings. Historians and anthropologists come from different intellectual traditions. The latter are concerned with patterns and regularities in human cultural and social evolution. Cohn writes:

«The units of study in anthropological history should be cultural and culturally derived: power, authority, exchange, reciprocity, codes of conduct, systems of social classification, the construction of time and space, rituals.» (1990: XIII)

Historians (with some exceptions) want to protect the integrity of the particular event, experience, circumstance. They seek to understand the patterns and causes of change. They offer contextualised assessment of events and personalities based on a thorough immersion in the sources. They paint on a wide canvass. And they are averse to the formulation of laws governing human behaviour. These points are obvious, but they need to be reiterated. Some 
historians who embrace anthropological concepts do not sufficiently appreciate that anthropology is a field, like any other, in flux, deeply divided over arcane theoretical matters, and thus run the danger of buying conceptual tools which might have gone past their use-by date. Similarly anthropologists who attempt history often do great violence to their subject by tearing events out of their context, and by not subjecting their sources to the rigorous assessment that historians routinely do.

Most Pacific historians of the Davidson school, like other historians, accepted the reality of the historical process and believed that a knowledge of the past could be attained through proper, disciplined, empirical, objective enquiry. That approach has come under challenge through post-modern analyses and Cultural Studies. The approaches and emphases vary, but certain common themes emerge: tentativeness and the inescapable subjectivity and relativity of knowledge, the fundamental unknowability of the past, the rejection of positivism and empiricism and «meta-narratives». These new ways alert us to the complex formations and realities of new forms of knowledge, power relations in society, ideologies, institutions and practices that underpin systems of political and economic domination. They purport to empower the powerless and the marginalised; they subvert authority and the accepted dogmas; they displace dualities in favour of shaded meanings; they suggest new dialectics between the past and the present.

Many Pacific historians embrace these ideas in moderation while discarding the mystifyingly unreadable prose in which they are sometimes expressed. Sometimes the exercise becomes a linguistic mind game, a «discursive practice», an end in itself, its practitioners disabled by doubt, infected by the virus of extreme relativism. Deconstruction may be intellectually exciting in the halls of academia and in the pages of academic journals, but it has limited relevance to the larger public debates in the society where, among so much fragmentation and division, the need for a common, unifying space is urgent. Epeli Hau'ofa's moving pieces about the need for Pacific islanders to forge overarching regional, Oceanic, identity that transcends narrow boundaries can be dismissed as a «totalising project», but it is an urgent matter to those who live in the islands. Fijian scholars at the University of the South Pacific are engaged in a massive process of social reconstruction and nation-building, forging a national, multiracial identity for that deeply polarised country.
Such an engagement calls for passionate commitment, not distance and detachment. For many Pacific islanders, the explosion of nuclear devices in their region was not a discourse; it was an act of environmental terror and vandalism that needed to be opposed. The military overthrow of a democratically elected government was a violation of some cherished principles that civilised society holds dear. The fact that some indigenous people used the barrel of the gun to overthrow the Labour Coalition government in Fiji does not make the overthrow right or legitimate. The discourse of pain, exploitation, discrimination, poverty, homelessness is not the same as the reality of pain, exploitation, discrimination, poverty and homelessness. The complex and untamed realities of everyday life cannot be reduced to a simple problematic.

This position would not be popular with those who want to exclude «outsiders» from commenting on island or indigenous affairs. Some of this anger is understandable because the islands have been used all too often as the intellectual laboratory of western academics who have sometimes shown little enduring commitment to them. But the question of who is an outsider is not simple. We all know of islanders who sell their services and resources to outsiders for personal gain or advantage. One recalls the forestry saga in Papua New Guinea and the Solomons, to take just one example. And we all know outsiders who have been passionate in the defence of indigenous issues: Ron Crocombe comes to mind immediately. In the fundamental analysis, the past is a foreign country to all of us; the only keys to that past are understanding, patience, knowledge, language skills and cultural sensitivity, not necessarily ethnicity or gender or class. Edward Said's words are worth heeding:

«If one believes with Gramsci that an intellectual vocation is socially possible as well as desirable, then it is an inadmissible contradiction at the same time to build analyses of historical experience around exclusions, exclusions that stipulate, for instance, that only women can understand feminine experience, only Jews can understand Jewish suffering, only formerly colonial subjects can understand colonial experience.» (1993: 35)

The shared understandings of what the past, and the study of that past, involve is being tested in unusual ways, some of it liberating and some of it alarming. Once, island academics trained in western universities were expected to imbibe and propagate the rituals and culture of the profession. They wrote in the approved traditions of the discipline: rigorously argued, well written, empirically rich and amply documented texts 
constructed from primary sources were the passport to success and academic respectability. Sione Latukefu took umbrage at the suggestion that he did not write like a Tongan or, indeed, a Pacific Islander, the implication being that he did not bring to his writing the information and knowledge that he was privy to as a Tongan. Latukefu responded that he wrote like a historian, who just happened to be Tongan and who should, therefore, be subject to the same standards of assessment and scrutiny as his colleagues. Latukefu and many like him were a part of what might be called the pioneering assimilationist tradition in Pacific scholarship. The prevailing intellectual climate as well as the imperatives of the profession encouraged that tradition.

They still do for people who live and work in metropolitan universities. Promotion and rewards in the academy are based on stringent criteria, foremost among them being the publication of articles in refereed journals and books by big-name publishers. Good reviews matter, along with the arithmetic of the Social Science Citation Index. Sometimes the obsession with the rituals of validation is excessive, but on the whole, the process is rigorous. It is also so in islands universities, though more notable there is the rejection of the western academic conventions by younger academics: political scientists write poetry, historians express their «feelings» through creative fiction and drama, social anthropologists do creative arts. The "talanoa», relaxed island style conversation, is for some the preferred form of academic communication.

Some of this is liberating, having the thrill of defiance and rebellion against the accepted canons and norms of the academy, a far cry from the uncritical acceptance of the earlier professional dogma. It is a form that should have a place in our system, but it would be sad if it became the only, or even the dominant, validated form. Still, some of it is also disconcerting. Here I declare my self-interest and prejudice. I belong to a tradition and a generation which does not regard a few lines of mangled English as poetry. Grammatically incorrect «english» that passes for modish prose is, for me, an exercise in language abuse. William Shakespeare, Matthew Arnold and John Steinbeck are not, for me, Dead White Males whose works have no relevance. I read them with the same devotion and interest as I read Albert Wendt and MG Vassanji, Chinua Achebe and Prem Chand. And great poetry often provides deeper insights into the human condition than post-modern theory: TS Eliot and Stanley Merwyn are good examples.
I worry what this trend portends for the future: island academics in local and regional institutions, improvising locally suitable means for communicating among themselves, rejecting the more conventional forms of scholarly discourse. It may create a fleeting sense of personal empowerment or register an act of protest against the «establishment». It will also detract from the urgent task, to be undertaken by island scholars themselves, of providing reasoned and uncompromising analyses of a host of problems facing the island nations.

I speak from experience and from a deep sense of commitment to the islands. I am not indigenous, as Les Murray would say, I was merely born there. I have seen too many of us succumb to the temptations of public office, enticed by the lucrative salaries of the international bureaucracy, or lulled into a false sense of superiority about our own credentials, and as a result performing far below our real potential. We all have our reasons. It would be good, for ourselves and for those who look to us for leadership and inspiration, if more of us entered and remained in the academy, as full partners, not merely as participant observers or providers of ethnographic facts for other people's theories. Jim Davidson wrote long ago:

«The advancement of learning is, primarily, a matter of recognizing new problems and asking new questions.» (1966: 11-12)

Thirty years later, his successor as the Professor of Pacific History at The Australian National University, Donald Denoon, wrote:

«Theoretical rigour alone does not make great teachers and writers. It certainly helps, but has no value without three qualities, which are hard to teach but vital to cultivate: imagination in asking questions, passion in researching them, and poetry in expression.» (Munro, 1996: 212)

Let new generations embrace these values as they stake claims and stamp their distinctive mark on the field. Let them by all means embrace new forms of knowledge where relevant and appropriate. But let us not reject out of hand the humane, intellectually liberal and morally engaged traditions of our discipline and of our founding ancestors. Let us engage with the Pacific's past as well as its present in the intelligent language of ordinary discourse. Let us continue to search for tangible, verifiable and knowable truths with passion and imagination. Let us once again proclaim the fundamental truth that History matters. Let us, finally, recognise that it is within our reach to make of History what we like, including arcane and irrelevant. And dead. 


\section{BIBLIOGRAPHY}

Cunning gham Adrian and Ewan Maidment, 1996. The Pacific Manuscripts Bureau: Preserving and disseminating Pacific documentation, The Contemporary Pacific: A Journal of Island Affairs 8 (2), pp. 443-455.

CoHn Bernard, 1990. An Anthropologist Among Historians and Other Essays, Delhi, Oxford University Press.

Davidson J.W., 1966. Problems of Pacific History, Journal of Pacific History 1, pp. 5-21.

Denoon Donald, 1996. An Accidental Historian, in Doug Munro (ed.), Reflections on Pacific Historiography, special issue of The Journal of Pacific Studies 20, pp. 209-212.

Denoon Donald et al. (eds), 1997. The Cambridge History of the Pacific Islanders, Cambridge, Cambridge University Press.

Douglas Bronwen, 1992. Doing Ethnographic History: Reflections on Practices and Practising. in Brij Lal (ed.), Pacific Islands History: Journeys and Transformations, Canberra, Journal of Pacific History Monograph, pp. 92-106.

FirTH Stewart, 1979. On Being a Historian of the Pacific, in John Moses (ed.), Historical Disciplines \& Culture in Australaasia, St. Lucia, University of Queensland Press, pp. 119-132.

FRANCE Peter, 1969. Charter of the Land: Custom and colonisation in Fiji, Melbourne, Oxford University Press.

Gunson Niel, 1992. An Introduction to Pacific History, in Brij Lal (ed.), Pacific Islands History: Journeys and Transformations, Canberra, Journal of Pacific History Monograph, pp. 1-13.

Hau'ofa Epeli, 1993. A New Oceania: Rediscovering Our Sea of Islands, Suva, USP, School of Social and Economic Development.

Howe Kerry R., 1979. Pacific History in the 1980s: New directions or monograph myopia?, Pacific Studies 3 (1), pp. 81-90.

Howe Kerry R, 1992. The future of Pacific Islands History: A Personal View, in Brij Lal (ed.), Pacific Islands History: Journeys and Transformations, Canberra, Journal of Pacific History Monograph, pp. 225-231.

Kiste Robert, Kerry R. Howe and Brij V. LaL (eds), 1994. Tides of History: The Pacific Islands in the
Twentieth Century, Honolulu, University of Hawaii Press.

Lal Brij V. (ed.), 1992. Pacific Islands History: Journeys and Transformations, Canberra, Journal of Pacific History Monograph.

Lal Brij V. and Kate Fortune (eds), 2000. The Pacific Islands: An encyclopedia, Honolulu, University of Hawaii Press.

Macdonald Barrie, 1996. Now an island is too big: Limits and limitations of Pacific Islands history, in Doug Munro (ed.), Reflections on Pacific Historiography, special issue of The Journal of Pacific Studies 20, pp. 23-44.

Maude H.E., 1968. Of Islands and Men: Studies in Pacific History, Melbourne, Oxford University Press.

-, 1971. Pacific History: Past, present and future, Journal of Pacific History 6, pp. 3-24.

Meleisia Malama, 1985. Book Review Forum, Pacific Studies 9 (1), pp. 147-149.

-, The Making of Modern Samoa, Suva, Institute of Pacific Studies.

Munro Doug (ed.), 1996. Reflections on Pacific Historiography, special issue of The Journal of Pacific Studies 20.

Munro Doug, 1996. The Isolation of Pacific History, in Doug Munro (ed.), Reflections on Pacific Historiography, special issue of The Journal of Pacific Studies 20, pp. 45-68.

OBEYSEKERE Gananath, 1992. The apotheosis of Captain Cook: European mythmaking in the Pacific, Princeton, New Jersey, Princeton University Press.

SAHLINS Marshall, 1995. How 'Natives' Think: About Captain Cook, for example, Chicago, University of Chicago Press.

SAID Edward, 1993. Culture and Imperialism, London, Chatto and Windus.

SHINEBERG Dorothy, 1996. The early years of Pacific History, in Doug Munro (ed.), Reflections on Pacific Historiography, special issue of The Journal of Pacific Studies 20, pp. 1-16.

Thomas Nicholas, 1990. Partial Texts: Representation, Colonialism and Agency in Pacific History, Journal of Pacific History 25 (2), pp. 139-158.

_, 1990. Sanitation and Seeing: The Creation of State Power in Early Colonial Fiji, Comparative Studies in Society and History 32, pp. 149-170. 